\title{
Straf for miljøforbrydelser i Island
}

\author{
Af Ragnheiður Bragadóttir ${ }^{1}$
}

In Icelandic law, penal provisions are contained in the Penal Code, or in various special criminal statutes. The Penal Code, Act no. 19/1940 contains, with the provisions on individual types of crime, provisions of general applicability in the context of criminal offences, sentencing being one of them. The Penal Code contains provisions which are not enacted with a view to offences against the environment, but might nevertheless be applied on account of such offences. Besides there is a provision in the Penal Code, on serious offences against the environment, enacted in 1999. No comprehensive legislation on matters of environmental impact has been enacted in Iceland, similar to the Acts on the environment in the other Nordic countries. Instead there are some statute law on environmental matters. They may be divided into the following categories: Acts on nature conservation, Acts protecting wildlife, Acts on protection against land, water and air pollution, Act in respect of prevention of marine pollution. Offences against these Acts are punishable by fines or imprisonment of up to two or four years. Some of the Acts make legal persons as well as natural persons criminally liable. Only few judgments have been passed where these provisions have been at issue and sentences for the offences are usually lenient.

\section{Indledning}

I islandsk ret findes der forskellige hjemlede foranstaltninger til beskyttelse af miljøet. Først kan der nævnes visse generelle begrænsninger, hvor man af hensyn til miljøet begrænser herredømmet over ejendomsgoder. Der kan enten være tale om ekspropriation, hvor den berettigede opnår fuld erstatning, eller almene indskrænkninger, hvor man ikke opnår erstatning. Endvidere er der bestemmelser om en særlig godkendelse fra myndighederne for at kunne drive virksomheder, som skønnes at kunne medføre forurening. Erstatningsansvar på grund af miljøskader kan gøres gældende ifølge love på nogle områder, men ellers ifølge erstatningsrettens almene regler. Til sidst så indeholder loven forskellig hjemmel til anvendelse af straf, samt andre strafferetlige retsfølger for overtrædelser inden for

* Title in English: Sentencing for environmental offences in Iceland. Original in Danish. 
miljøområdet. Det er naturligt at der er mulighed for at andvende straf og andre strafferetlige sanktioner hvis loven overtrædes, fordi forbrydelser mod miljøet ofte kan have alvorlige følger, både for individer og samfund. Det fremgår også $i$ forarbejderne til nogle islandske love på miljøområdet at lovgiverens vilje er at man skal straffe hårdt for miljøforbrydelser. ${ }^{2}$

Bestemmelser om strafbare forhold findes enten i straffeloven, ${ }^{3}$ som er hovedloven på det strafferetlige område i Island, eller i speciallovgivningen. Straffeloven deles i almindelig del og speciel del. I straffelovens almindelige del er der almene bestemmelser om ansvarsbetingelser, fx typicitet, objektive og subjektive straffrihedsgrunde, tilregnelse, tilregnelighed, forsøg og medvirken, forældelse, straf og strafudmåling. I straffelovens specielle del er der bestemmelser om forskellige forbrydelser. Speciallove er alle de love uden for straffeloven hvor der er foreskrevet straf for overtrædelser. Straffelovens almindelige del finder anvendelse på alle strafbare forhold som er beskrevet i selve straffeloven. Det samme gælder forhold beskrevet i speciallovgivningen medmindre andet er bestemt $i$ en speciallov. Undtagelse derfra er bestemmelserne om forsøg og medvirken som ifølge straffeloven kun anvendes på straffelovsforbrydelser.

I Island er der ikke blevet vedtaget en samlet lovgivning angående miljøspørgsmål og forurening, med tilhørende straffebestemmelser, som man har lovfæstet i de andre nordiske lande. Der var en diskussion om at vedtage en sådan lovgivning for ca. 30 år siden og der blev forelagt Altinget et lovforslag derom nogle gange, men uden at det blev vedtaget. Det ser ud til at i tidens løb er man vendt fra planer om en samlet miljølov samtidig med at man antog at oprettelsen af et miljøministerium i 1990 ville række til at sikre overensstemmelse i lovgivning og praksis. Til trods for at der mangler en samlet lovgivning inden for dette område indeholder mange love bestemmelser angående miljøspørgsmål og straf for miljøforbrydelser. Disse love stammer fra forskellige tidsperioder. De fleste er helhedslove om bestemte områder og det er forskelligt hvor præcise deres bestemmelser er i henhold til sanktioner, hvis der er begået strafbare handlinger på lovenes områder. I det følgende bliver der gjort rede for strafudmåling for miljøforbrydelser, både ifølge straffeloven og speciallovgivningen. Men først kommer der en kort redegørelse for regler som er af betydning ved udmåling af straffen.

\section{Almene regler om udmåling af straf}

Strafferammen i de enkelte bestemmelser om forbrydelser fastlægger det spillerum lovgiveren har givet domstolene til udmåling af straffen. Forskellige faktorer har betydning, når dommeren fastsætter straffen for miljøforbrydelser. Det gælder såvel miljøforbrydelser ifølge straffeloven som speciallovgivningen. Disse fakto- 
rer kan enten være lovbestemte eller ikke-lovbestemte. Strafudmåling kan finde sted med henvisning til formildende eller skærpende omstændigheder inden for den pågældende bestemmelse om miljøforbrydelse. Den kan også henvise til generelle strafnedsættelses-/strafforhøjelsesgrunde, som åbner mulighed for at overskride både strafferammens minimum og maksimum.

I straffeloven findes der fire paragraffer om almene strafnedsættelsesgrunde, som kan finde anvendelse på såvel miljøforbrydelser som andre forbrydelser. Disse strafnedsættelsesgrunde er alle fakultative og når de kan citeres, er det muligt at sænke straffen ned under bestemmelsens strafminimum. De er: $\S 20$ om forsøg; $§ 22$ om medvirken; $§ 74$ om forskellige forhold, der hjemler nedsættelse af straffen, fx hvis gerningsmanden har af egen fri vilje, efter fuldbyrdelse af forbrydelsen, forhindret den fare den medførte, hvis han har af egen fri vilje ydet erstatning for skaden som forbrydelsen medførte, eller han har anstrengt sig for at forhindre skadelige følger af handlingen; $§ 75$ om strafnedsættelse hvis der foreligger omstændigheder, der gør handlingen mindre strafværdig. I praksis virker strafnedsættelsesgrundene næsten udelukkende formildende inden for strafferammen.

I straffelovens $\S 70$ nævnes de forhold, der skal tages i betragtning ved udmåling af straffen, og som kan virke enten skærpende eller formildende inden for bestemmelsens strafferamme. Disse forhold angår først og fremmest gerningsmanden og hans handling. Her kan nævnes betydningen af de interesser forbrydelsen rammer, omfanget af de skader forbrydelsen har forvoldt og den fare, der var forbundet med handlingen, herunder især spørgsmålene om hvornår, hvor og hvorledes forbrydelsen blev begået. Gerningsmandens motiv og hans optræden efter forbrydelsen er også af betydning.

Ved udmåling af en bøde skal der tages hensyn til den dømtes indtægter og ejendom, og den berigelse og besparelse som han fik af forbrydelsen eller prøvede at få af den, jf. straffelovens $\S 51$. Ifølge $\S 49$ er det muligt at idømme bøde, i tillæg til den fængselsstraf forbrydelsen skal straffes med, når tiltalte ved lovovertrædelsen har opnået eller tilsigtet at opnå økonomisk vinding for sig selv eller andre. Gevinst af forbrydelser eller et hertil svarende beløb kan helt eller delvis konfiskeres. Savnes der fornødent grundlag for at fastslå beløbets størrelse, kan der konfiskeres et beløb, som skønnes at svare til det indvundne udbytte, jf. § 69 a.

I straffelovens $\S 57$ om betingede domme findes der bl.a. en hjemmel til at udsætte fuldbyrdelsen af straffen på visse betingelser. Der findes ingen direktiver i loven om, hvilke domme der kan gøres betingede, hverken for så vidt angår straffens størrelse eller forbrydelsens art, men der har dannet sig en retspraksis på om- 
rådet. De væsentligste argumenter for betingede domme er gerningsmandens unge alder og en pletfri vandel. Det er imidlertid meget sjældent, at en frihedsstraf på mere end et års fængsel gøres betinget.

I speciallovgivningen inden for miljøområdet findes der bestemmelser om skærpende omstændigheder, fx alvorlige forbrydelser, grove eller gentagne forsætsforbrydelser eller hvis genstande for forbrydelser ifølge fredningslove er sjældne fuglearter eller fredede ynglesteder.

\section{Miljøforbrydelser ifølge straffeloven \\ Almenfarlige forbrydelser}

Straffeloven stammer fra 1940, og på den tid var diskussion om miljøbeskyttelse ikke særlig aktuel, i det mindste ikke i samme forstand som nu. Til trods for det findes der i straffeloven bestemmelser, der muligvis kunne anvendes i forbindelse med overtrædelser inden for miljøområdet, selvom de ikke blev vedtaget med miljømæssige overtrædelser for øje. Disse bestemmelser findes i straffelovens kapitel XVIII „Almenfarlige forbrydelser" og kapitel XIX „Forskellige almenskadelige handlinger". Disse bestemmelser har været uændret i straffeloven fra året $1940 \mathrm{og}$ de er meget sjældent blevet anvendt af anklagamyndigheden og domstolene. Ifølge $\S 165$, stk. 1, straffes der med fængsel fra 30 dage indtil 16 år for forsætligt at forvolde sprængning, spredning af skadevoldende luftarter eller oversvømmelse med følgende skade på andres liv, legeme eller ejendele. Uagtsomme forbrydelser mod $\S 165$ er starfbare ifølge $\S 167$, og straffes med bøde eller fængsel indtil 3 år. Der findes kun én dom om spredning af skadevoldende luftarter ifølge $\S 165$, dvs. en dom fra byretten i Østisland i 2007.

Byretten i Østisland 28. juni 2007 (nr. S-48/2007). S, produkthandler og underdirektør for et olieselskab, blev tiltalt for overtrædelse af straffelovens $\S 165$, stk. 1 , jf. $\S 167$, ved uagtsomt at forvolde spredning af en giftig luftart, klorgas, i svømmehallen i den lille landsby Eskifjörður. S ekspederede eddikesyre i stedet for kloropløsning i en tank for brug i svømmehallen og gav ordre til X, en ung mand som arbejdede hos olieselskabet i sin sommerferie, om at transportere tanken til Eskifjörður og pumpe tankens indhold i svømmehallens klortank. Derved dannedes klorgas som spredtes vidt i området og 45 mennesker blev sundhedsmæssigt beskadiget. S blev dømt skyldig og straffen udmålt til 30 dages fængsel betinget i 2 år. X blev frifundet, fordi dommeren mente at han ikke havde handlet uagtsomt.

Ifølge $\S 169$ er det en strafbar undladelse ikke at advare eller afværge bl.a. sprængning, spredning af skadevoldende luftarter og oversvømmelse. Denne afværgepligt er uafhængig af om fx forureningen skyldes en strafbar handling eller 
ej. Men det må være muligt for gerningsmanden at afværge faren, uden særlig fare eller opofrelse for ham selv eller andre. Subjektivt er ansvar betinget af forsæt og forbrydelsen straffes med bøde eller fængsel indtil 1 år. I speciallovgivningen er der mange bestemmelser om handlepligt, som må ses i sammenhæng med straffelovens $\S 169$, fx regler om mange slags sikkerhedsforanstaltninger. Hvis man forsætligt tilsætter vandbeholdninger eller vandledninger sundhedsfarlige stoffer, straffes det med fængsel indtil 12 år, jf. straffelovens $\S 170$, stk. 1. Bestemmelsen omfatter vandbeholdninger og vandledninger, som henviser til kunstige drikkevandsreservoirer. Grundvandsforurening er derfor ikke strafbar ifølge denne bestemmelse, men til gengæld kan speciallovbestemmelser anvendes. ${ }^{4}$ Straffelovbestemmelsernes beskyttelsesinteresse er menneskers liv, helbred og ejendom, men ikke selve miljøet, selv om det naturligvis kan blive udsat for forurening og anden beskadigelse.

\section{Grove forbrydelser mod miljølovgivningen}

I 1999 blev der tilføjet en ny bestemmelse i straffeloven, § 179, med forbillede i de danske og norske bestemmelser om emnet. Den handler om grove forbrydelser mod miljølovgivningen. Der står: Med fængsel indtil 4 år straffes den, som begår grove forbrydelser mod love om beskyttelse af miljøet med det følgende: 1) Forurener luft, jord, hav eller vand med den følge, at der sker betydelig skade på miljøet eller fremkaldes nærliggende fare derfor. 2) opbevarer eller bortskaffer affald eller beskadigende stoffer med den følge, at der sker betydelig skade på miljøet eller fremkaldes nærliggende fare derfor. 3) bringer naturen i uorden således at landskabet ændrer sig varigt eller beskadiger vigtige naturminder.

Hensigten med denne bestemmelse i straffeloven var i højere grad at give bestemmelser i miljølovgivningen præventiv virkning, således at de alvorligste miljøforbrydelser straffes ifølge straffeloven. Der går man ud fra, at straf for straffelovsforbrydelser har alment stærkere præventiv virkning end straf for forbrydelser mod andre love. Det var også hensigten at fremhæve hvor alvorlige disse forbrydelser er, samt at de skulle straffes hårdt. Det er den samme lovteknik som der eksisterer i forbindelse med narkotikaforbrydelser og grove forbrydelser mod lovgivning om skatte- og bogholderi. Bestemmelsen om straf for grove miljøforbrydelser er aldrig blevet brugt af anklagemyndigheden og dermed ikke af domstolene.

\section{Miljøforbrydelser ifølge speciallovgivningen}

Til trods for at der mangler en samlet lovgivning inden for miljøområdet indeholder mange love bestemmelser angående miljøspørgsmål og faktisk er miljøet et 
centralt emne i mange af disse love. Speciallovene på miljøområdet kan deles op i fire kategorier: Love om beskyttelse af naturen, love om beskyttelse af vilde fugle og pattedyr, love om forurening af land og luft, og til sidst love om forurening af hav og strande. ${ }^{5}$

Alle disse love indeholder straffebestemmelser. Disse bestemmelser er ikke altid klare og ofte påbydes der straf for overtrædelser af lovene uden at der nærmere gøres rede for forbrydelsens gerningsindhold. De fleste af bestemmelserne placerer strafansvar hos individer, og de forudsætter skyld. Ifølge nogle af lovene kan strafansvar både pålægges juridiske personer og individer. Overtrædelser mod lovene straffes, ifølge lovenes bestemmelser, med bøde eller fængsel. Ved strafudmåling kan der henvises til generelle strafnedsættelses- og strafforhøjelsesgrunde i straffeloven, samt til skærpende og formildende forhold.

\section{Beskyttelse af naturen}

Den vigtigste lov på dette område er lov nr. 44/1999 om naturbeskyttelse (nvl.). Det er en almindelig lov om beskyttelse af islandsk natur. I loven er der mange bestemmelser om hvordan man skal opføre sig ude i naturen så at den ikke bliver beskadiget. Sidst i loven, i § 75, står at den som uagtsomt eller forsætligt beskadiger Islands natur på en ulovlig måde skal straffes ifølge § 76, men ifølge den paragraf straffes forbrydelser mod loven med bøde eller fængsel indtil to år. Med lov nr. 20/2012 blev det tilføjet, at alvorlig beskadigelse på landets natur straffes med bøde mindst IKR 350.000, eller fængsel indtil fire år. Bødens mindstebeløb skal ændres hver måned ifølge indeksregulering. Det er derfor klart at opførsel som strider mod loven kan straffes. Men det er ikke sikkert at enhver opførsel imod loven er strafbar. Det er nødvendigt at undersøge hver enkelt af lovens bestemmelser og få afgjort om de lever op til de krav der gøres til straffebestemmelsers klarhed. I loven er der ingen hjemmel til at straffe juridiske personer.

Den mest almindelige overtrædelse af nvl. er kørsel udenfor veje. I lovens $\S$ 17 er der en bestemmelse om forbud mod kørsel udenfor veje hvor stk. 1 lyder sådan: "Det er forbudt at køre motordrevne køretøjer udenfor veje. Det er dog tilladt at køre disse køretøjer på gletsjere, såvel som på sne udenfor veje udenfor byer såfremt jorden er frossen og dækket med sne.“ I § 17. stk. 3 i nvl. står der at ulovlig kørsel udenfor veje straffes med bøde eller fængsel indtil 2 år ifølge lovens $\S 76$. Med loven fra $2012 \mathrm{blev}$ der lovfæstet en mulighed for at konfiskere køretøjer i alvorlige tilfælde. Der er afsagt meget få Højesteretsdomme om kørsel udenfor veje. Fra året 1999, i den nugældende nvl.'s gyldighedsperiode, er der kun to, begge fra året 2007. Der er endvidere afsagt nogle byretsdomme. I disse 
domme er spørgsmålet tit hvad defineres som en vej. Dette var tilfældet i den ene af de to Højestretsdomme.

H 22. marts 2007 (nr. 331/2006): X blev tiltalt for overtrædelse af $\S 17$, stk. 1., jf. stk. 3 i nvl., jf. § 76 og en bekendtgørelse fra 1998 om kørsel i ødemarken ved at køre udenfor veje på Skeiðarársandur, som er en vidtstrakt sandørken syd for Vatnajökull gletsjer, og volde skader der. X var i sandørkenen for at lede efter det hollandske fraktskib Het Vaapen van Amsterdam som strandede ved kysten i 1667 med en stor guldlast og formodes begravet i sandet. Området som han kørte gennem er nogle steder bevokset med vegetation og terrænnet blødt og vådt, men det var muligt at skimte hjulspor. Andre steder var det ikke muligt at skimte klare hjulspor eftersom der flyder vand $i$ vandløb over sandet og overfladen ændres hele tiden. Med henvisning til dette og vidneforklaring om en meget begrænset trafik over sandørkenen anså byretten, at ruten som X kørte ikke var en vej ifølge trafikloven. Undtagelsesbestemmelser om tilladt kørsel udenfor veje passede ikke her og X blev derfor idømt IKR 50.000 bøde med en forvandlingsstraf 4 dages fængsel. Højesteret kom til en anden konklusion. Den henviste til at ruten længe har været kendte spor som man tidligere havde kørt efter for at fange sæler og indsamle drivtømmer. X og hans kammerater havde i flere årtier kørt denne rute på grund af deres søgen efter det hollandske fragtskib og i dette arbejde bl.a. fået bistand fra Instituttet for energi. Endelig var hjulsporene markeret på et kort som Det amerikanske forsvarsministeriums Kartografiske institut og Islands geodætiske institut udgav i 1988. Med henvisning til alt dette anså Højesteret at hjulsporene var en vej ifølge nvl., eftersom al fornuftig tvivl burde fortolkes derom til X's fordel. Han blev derfor frifundet.

Forbuddet mod kørsel udenfor veje ifølge $\S 17 \mathrm{i}$ nvl. indebærer korrelatforbrydelse, dvs. alene det at køre udenfor veje er strafbart og det er ikke en betingelse at dette har følger, så som synlige spor eller skader på landskab eller vegetation. I den anden højesteretsdom fra året $2007 \mathrm{blev}$ der forvoldt skader på naturen med en bulldozer der blev brugt til at rydde nye hjulspor.

H 18. januar 2007 (nr. 458/2006): J blev tiltalt for at have ryddet knap $4 \mathrm{~km}$ lange hjulspor for at anlægge en ridesti ad en rute som X markerede ved at gå foran en stor bulldozer som J styrede. Der var ikke givet tilladelse til anlægget og sporene lå gennem et uberørt bevokset område, der blev skadet permanent. I tiltalen anså man bl.a. at overtrædelsen faldt under § 12, stk. 2 i nvl., hvor der står at alle har pligt til at vise hensyn $i$ omgang med landets natur og udvise forsigtighed således at den ikke bliver skadet. Højesteret anså at denne bestemmelses ordlyd var almen og ikke opfyldte de krav som man må gøre til straffebestemmelsers klarhed. J blev derfor ikke dømt skyldig for overtrædelse af denne bestemmelse. 
På den anden side anså man, at hans overtrædelse faldt under $\S 17$, stk. 1, jf. $\S 76$ i nvl. om kørsel udenfor veje, og desuden blev bestemmelser i byplans- og byggelov anvendt om overtrædelsen. J blev idømt bøde på IKR 200.000 med en forvandlingsstraf af fængsel i 14 dage. X blev idømt samme straf $\mathrm{i}$ byretten, men han ankede ikke dommen.

Det er klart, at der er forskellige problemer forbundet med opfølgning af lovens forbud mod at køre udenfor veje. Dette har rod i selve bestemmelserne, som ikke er klare nok. Dertil kommer at Island er både stort og mange steder uvejsomt så der er svært at holde opsyn med at loven ikke bliver overtrådt. ${ }^{6}$

\section{Beskyttelse af vilde fugle og pattedyr}

Lov nr. 64/1994 om beskyttelse, fredning og jagt af vilde fugle og vilde pattedyr omfatter alle fugle og pattedyr, undtagen sæler, hvaler, kæledyr og husdyr. Loven er rammelov og der er mange bekendtgørelser som er blevet udstedt ifølge loven. Lovens formål er at forene fredningshensyn med udnyttelse af vilde pattedyr og fugle. Hovedreglen er at alle vilde pattedyr og fugle er fredede undtagen andet er bestemt ifølge loven. Der er udførlige regler om hvilke pattedyr og fugle det er tilladt at jage, hvor, hvordan og hvornår. Ifølge $\S 21$ straffes forbrydelser mod loven med bøde eller fængsel indtil to år, samt frakendelse af våben- og jagttilladelse. Det har en strafskærpende virkning hvis der jages sjældne eller specielle fuglearter. Det samme gælder edderfugl og dens æg, samt grov ulovlig fuglejagt og beskadigelse af fredede ynglesteder. Miljøministeren kan udgive bekendtgørelse med forbud mod salg af de fugle og deres produkter, som han har tilladt at jage, hvis det er nødvendigt at begrænse jagten på grund af bestandens tilstand. Juridiske personer kan straffes for forbrydelser mod denne bestemmelse, men ikke andre bestemmelser i loven. Ulovlig fangst, æg eller æggeskal, jagtredskaber og andet som er anvendt ved jagten, samt udbytte af ulovlig jagt og salg, kan konfiskeres.

Der er afsagt meget få domme om forbrydelser mod lov nr. 64/1994 og næsten ingen Højesteretsdomme i de sidste år. De få domme der findes handler om ulovlig jagt på rensdyr eller ryper, eller sjældne fugle som falke. Der er nogle underretsdomme, ikke mindst fra Østisland om ulovlig rensdyrjagt. Følgende Højesteretsdomme viser klart at straf for forbrydelser mod loven er meget milde.

H 8. februar 2001 (nr. 432/2000): Tiltalte skød tre rensdyr hanner i Østisland uden at have guide, som altid skal følge jægerne på rensdyrjagt. Straffen blev fastsat bøde på IKR 35.000 med en forvandlingsstraf af fængsel i 7 dage.

H 23. maj 2001 (nr. 127/2001): Tiltalte havde skudt to rensdyr hanner i Nordøstisland uden at have en guide, uden jagttilladelse og uden at have fået udgivet jagtkort. I dommen er det oplyst at jagttilladelse for én rensdyr han, i det område 
hvor tiltalte opholdt sig ved jagten, kostede IKR 90.000. Straffen blev fastsat bøde på IKR 200.000 med en forvandlingsstraf af fængsel i 30 dage.

I en ældre dom var der udmålt meget strengere straf.

H 1993.1049: V og P fjernede fra en rede i Nordøstisland to falkeunger der ikke var flyvefærdige. De transporterede ungerne med en færge til Danmark for at sælge dem der, men blev anholdt forinden. Lidt senere tog de fra en rede i Vestisland to dværgfalkeunger, der ikke var flyvefærdige. Den ene falkeunge havde et brækket ben og måtte aflives, men den anden dværgfalkeunge havde stærkt beskadigede fjer i hale og vinge. $\mathrm{V}$ og $\mathrm{P}$ havde overtrådt dagældende lov om fuglejagt og fredning af fugle. De fik begge to 3 måneders ubetinget fængsel i byretten. Det var strafskærpende at de begik deres forbrydelser imod landets sarte natur med det øjemed at få en betydelig gevinst og kom til Island særskilt derfor. Det var også klart at de havde behandlet fuglene dårligt. De blev også idømt bøde, IKR 200.000 hver for sig med en forvandlingsstraf af fængsel i 40 dage. Dommen blev stadfæstet i Højesteret, dog således at 2 måneder af P's straf var betinget.

\section{Forurening af land og luft}

Der er nogle speciallove på strafferetsområdet gældende om forurening af land og luft. Den almindelige lov derom er lov nr. 7/1998 om sundhedsforanstaltninger og beskyttelse mod forurening (forureningsloven). Loven omfatter forurening fra alle virksomheder i islandsk territorium, dvs. land, luft og de 200 sømils økonomiske zone. Loven omfatter både det ydre miljø og indre miljø (indendørs).

Bestemmelserne i forureningsloven handler først og fremmest om forvaltningen af miljøsager og selve systemet. Selve loven siger intet om hvad det er, som er en strafbar handling eller strafbar undladelse. Men ifølge lovens $\S 5$ skal miljøministeren nedsætte bekendtgørelser om mange forskellige emner, fx beskyttelse mod forurening af luft, forurening af vand, forurening fra affald og sundhedsfarlige stoffer, om tilladelse til virksomheder som muligvis forurener, tilsyn, registrering og oplysningspligt, m.m. Selv om der er ingen gerningsbestemmelser i loven siger det i § 33, at forbrydelser mod lovens bestemmelser, regler fastsatte i henhold til loven og kommunernes vedtægter straffes med bøder. Alvorlige forbrydelser straffes med fængsel fra 30 dage og indtil 4 år, og med alvorlige forbrydelser menes grove eller gentagne forsætforbrydelser. For at fastsætte hvilken adfærd det er som er strafbar, er der blevet vedtaget en mængde af bekendtgørelser. I disse bekendtgørelser er der mange regler om påbud og forbud, og straf hvis man ikke følger reglerne. Mange af disse bestemmelser er dog mangelfulde og lever ikke op til de krav som man nu gør i islandsk ret til straffebestemmelsers 
klarhed. Gerningsmænd ifølge loven kan være både enkeltpersoner og juridiske personer. Juridiske personer kan straffes med bøde, uanset om der er begået en overtrædelse, der kan tilregnes dennes funktionære eller andre som arbejder på den juridiske persons vegne, hvis overtrædelsen medførte eller kunne have medført en gevinst for den juridiske person. I loven er der også bestemmelser om mange slags tvangsforanstaltninger som kan bruges, f.eks. påmindelse, frist til at råde bod på det som er gået galt, standse eller begrænse virksomhed. Det er også muligt at pålægge dagsbøder for at tvinge den skyldige til handlinger eller undladelser, og få lavet arbejde på den skyldiges bekostning.

Der er ikke forsket meget $\mathrm{i}$ Island om hvilke forbrydelser der er begået mod forureningsloven. Der findes dog en undersøgelse som er 10 år gammel og den viser at de fleste anmeldte sager ikke bliver til noget. Fra 1995 til 2000 var der fx 42 sager anmeldt til politiet i Reykjavík. Ingen af dem endte med dom. ${ }^{7}$

Der eksisterer ingen Højesteretsdom om strafferetlige spørgsmål i forbindelse med forureningsloven og der er kun to byretsdomme om forurening af land. I den ene var tiltalte frifundet men den anden er den følgende dom fra Vestfjordene.

Byretten i Vestfjordene, 18. juli 2003 (nr. S-49/2003). G flyttede husruiner og ca. 1000 kubikmeter jernaffald hen til en gård i Vestfjordene og begravede det nede ved havet uden tilladelse til den slags virksomhed. J, som var kommunens borgmester, havde bedt $\mathrm{G}$ om at udføre dette arbejde på kommunens vegne, mod betaling, selv om han vidste at $G$ ikke havde den nødvendige tilladelse. $G$ og J var begge to tiltalt, samt kommunen. I anklageskriftet henvises der til forureningsloven, § 5, jf. § 33, bekendtgørelse $\mathrm{nr}$. 785/1999 om tilladelse til virksomheder som kan medføre forurening og et bilag med bekendtgørelsen. - Kommunens sundhedsfuldmægtig fik på forhånd oplysninger om at $\mathrm{G}$ ville grave affaldet og skrev til kommunen, at der skulle søges en tilladelse hos Statens sundhedsvæsen, og anmodede om at nedgravningen skulle stoppes. Affaldet blev alligevel nedgravet. Politiet blev tilkaldt og beskrev forholdene således at der var en grøft fyldt med husruiner, jern og træ, og vand. I nærheden var der nogle fiskekar af plastik hvor der var ild. Politiet gjorde intet, men tre måneder senere anmeldte Statens sundhedstilsyn om forholdene til Statens politi i Reykjavík, efter forgæves at have forsøgt at få kommunen til at søge om tilladelse. - G blev domfældt, fordi det var ham som nedgravede affaldet uden tilladelse. J vidste at $\mathrm{G}$ ikke havde tilladelse, men fik ham alligevel til at udføre gerningen mod betaling og derfor blev han også domfældt. Kommunen var også skyldig ifølge reglerne i forureningsloven om juridiske personers strafansvar. G blev idømt IKR 200.000 bøde med en forvandlingsstraf 30 dages fængsel. J blev idømt IKR 400.000 bøde med en forvandlingsstraf 45 dages fængsel og kommunen blev idømt IKR 800.000 bøde. 
Dommen viser hvor ineffektivt systemet er. Det er selve kommunen og dens borgmester som deltager og ved at $\mathrm{G}$ ikke har tilladelse. De fortsætter med deres arbejde, selv om Statens sundhedsvæsen er kommet ind. Derefter kommer politiet, skriver en rapport, men gør så ingenting.

Der findes flere love om forurening, fx lov om giftstoffer og sundhedsfarlige stoffer, lov om behandlingen af affald og vandloven. Overtrædelser af lov nr. 55/2003 om behandlingen af affald, bekendtgørelser ifølge loven og kommunernes vedtægter straffes med bøde, jf. lovens $\S 50$. Overtrædelserne er strafbare hvad enten de er forsætlige eller grovt uagtsomme. Straffen kan stige til fængsel indtil 4 år hvis overtrædelserne er grove eller gentagne fortsætforbrydelser. Der findes én underretsdom om overtrædelse af lov nr. 55/2003.

Vestislands byret 2. juli 2007 (nr. S-67/2007): B arbejdede hos en virksomhed som tømte affald fra toiletter og kørte bort affaldet. Han blev anklaget for at have to gange en dag i sommeren 2006 kørt en lastbil udenfor veje i nationalparken Snæfellsnes og aflastet bilens kloakaffald i en hule i lavamarken. Der var tydelige hjulspor på marken, mængden af kloakaffaldet var betydeligt og stanken ikke til at gå glip af. B blev dømt skyldig ifølge naturværnlovens (nr. 44/1999) § 17, stk. 1 , og $\S 75$, jf. $\S 76$ (kørsel uden for veje), § 10 , stk. 1 og 2 , jf. § 24 , stk. 1 , i loven om behandlingen af affald $\mathrm{nr}$. 55/2003, bkg. om behandlingen af kloakaffald, bkg. om behandlingen af affald og bkg. om kloak og affald fra toiletter, jf. led 10 og 11 i $\S 5$, jf. $\S 33$ i lov nr. 7/1998 om sundhedsforanstaltninger og beskyttelse mod forurening (forureningsloven). Ved straffens fastsættelse lagdes der vægt på at B's overtrædelse af naturværnloven var meget bagatelagtig. Desuden var det oplyst, af både B og vidner, at hulen i lavamarken var i mange år blevet anvendt til aflastning af kloakaffald fra den lille landsby, Arnarstapi, med kommunens viden og uden bemærkninger fra denne, men det var kommunen som fik B til at udføre arbejdet. Med henvisning til led a i $§ 57$, stk 1 , i straffeloven var straffastsættelse udsat, betinget i 2 år.

Forurening af hav og strand

Lov nr. 33/2004 om beskyttelse mod forurening af hav og strand er den vigtigste lov om emnet. Loven bygger bl.a. på nogle internationale konventioner som Island har ratificeret og forbilledet er den danske lov om samme emne. Loven omfatter enhver aktivitet i forbindelse med virksomheder, skibe og luftfartøjer, der befinder sig på land, i luftterritoriet og på Islands strand, i søterritoriet, den økonomiske zone og kontinentalsokkelen, som forurener eller kan forurene hav og strand, bringe menneskets sundhed i fare, beskadige havets levende naturværdier og forstyrre dets biologiske system. På samme måde som ifølge forureningsloven 
skal ministeren fastsætte fyldigere regler med bekendtgørelser. Men der er den forskel, at i lov nr. 33/2004 om forurening af hav og strand er der mange forskellige gerningsbeskrivelser, $\mathrm{fx}$ om forbud mod udtømning og dumpning.

Overtrædelser mod loven straffes med bøde eller fængsel indtil 2 år, jf. § 25. Straffen kan stige til fængsel indtil 4 år, hvis der er tale om grove eller gentagne forsætforbrydelser. Juridiske personer kan straffes med bøde, uanset om der er begået en overtrædelse, der kan tilregnes dennes funktionære eller andre som arbejder på den juridiske persons vegne, hvis overtrædelsen medførte eller kunne have medført en gevinst for den juridiske person, jf. § 26. Det er den samme regel som den, som findes i forureningsloven. Desuden er det muligt ifølge lov nr. 33/2004 at straffe den juridiske person med bøde, hvis dennes funktionære eller andre som arbejder på den juridiske persons vegne begår forbrydelser eller det sker på grund af manglende teknisk udstyr eller arbejdsledelse.

Der findes kun én dom om strafansvar ifølge lov nr. 33/2004.

H 11. marts 1999 (nr. 262/1998): B og T var tiltalt for at trække et gammelt skib, som B ejede, fra stranden i en fjord i Vestfjordene, hvor det havde ligget $\mathrm{i}$ årevis, og ud på havet $\mathrm{i}$ fjorden, hvor de sænkede det. Der var ingen olie eller andre farlige stoffer i skibet da det blev sænket. Kommunen havde før sagsøgt B, for at få ham til at fjerne skibet og havde anvendt dagsbøder i det øjemed. Retten mente, at B og T måtte have forudset, at det var meget sandsynligt at skibet ville synke, hvis de trak det ud på fjorden (sandsynlighedsforsæt). B blev idømt IKR 2.500 .000 bøde med en forvandlingsstraf 5 måneders fængsel. T blev idømt IKR 500.000 bøde med en forvandlingsstraf 60 dages fængsel. Ved strafudmålingen tages i betragtning de vigtige almene interesser de tiltalte overtrådte og at overtrædelsen var udført af flere i forening. I tillæg var det strafskærpende for B at han tog initiativet til gerningen og viste med sin opførsel, efter at han begik forbrydelsen, at han ignorerede landets lov, men det var formildende at han derved ikke opnåede økonomisk vinding.

\section{Oversigt over domme for miljøforbrydelser 1984 til 2012}

I det følgende er der oversigt over Højesteretsdomme for miljøforbrydelser i Island 1984 til 2012. I tillæg er der nogle byretsdomme på de områder hvor der er ingen Højesteretsdomme.

\section{Straffeloven}

Byretten i Østisland 28. juni 2007 (klorgas i svømmehal): S: fængsel 30 dage, betinget; $\mathrm{X}$ : frifundet 
Beskyttelse af naturen

H 1993:1073 (kørsel udenfor veje): frifindelse

H 18. jan. 2007 (bulldozer på bevokset, uberørt område): bøde IKR 200.000 (14 dage $)^{8}$

H 22. marts 2007 (kørsel på sand): frifindelse

Beskyttelse af vilde fugle og pattedyr

H 1984:1341 (falkeæg): M: fængsel 3 mån.; G: bøde IKR 80.000 (60 dage). 8 falkeæg og redskaber konfiskeret.

H 1993:1049 (falke): V: fængsel 3 mån.; P: fængsel 3 mån., deraf 2 betinget

H 1994.1191 (isbjørnejagt): 5 mænd frifundet

H 1994:2227 (jagt af fugle): frifindelse

H 21. jan. 1999 (rypejagt på ejendomsland): frifindelse

H 6. maj 1999 (rypejagt på ejendomsland): S og E frifundet

H 8. feb. 2001 (rensdyrjagt): bøde IKR 35.000 (7 dage)

H 23. maj 2001 (rensdyrjagt): bøde IKR 200.000 (30 dage)

H 3. april 2003 (ørnens habitat): frifindelse

H 11. marts 2004 (fugleskydning på havet): B og S: bøde IKR 75.000 (15 dage). 74 fugle konfiskeret.

Forurening af land og luft

Byretten i Reykjanes 18. maj 1999 (brand ved havet): frifindelse

Byretten i Vestfjordene 18. juli 2003 (gravning uden tilladelse): G: bøde IKR 200.000 (30 dage); J: bøde IKR 400.000 (45 dage); kommune: bøde IKR 800.000 .

Forurening af hav og strand

H 11. marts 1999 (forurening af havet, skib sænket i havet): B: bøde IKR 2.500.000 (5 mån); T: bøde IKR 500.000 (60 dage)

\begin{abstract}
Alment om dommene
Der er kun 14 Højesteretsdomme om overtrædelser mod de love, som denne artikel handler om. De fleste af dem vedrører overtrædelser mod loven om beskyttelse af vilde pattedyr og fugle. Der findes også nogle byretsdomme om disse overtrædelser, samt byretsdomme om kørsel udenfor veje, ifølge loven om naturbeskyttelse. Der er kun tre domme som handler om forurening, deraf én Højesteretsdom. Da dommene er så få er det ikke muligt at drage generelle statistiske
\end{abstract}


konklusioner på grundlag af dem. Men det er muligt at sammenligne de enkelte domme og undersøge, hvilke faktorer der har størst vægt, når straffen fastsættes.

Straffene er meget milde, vanligvis bøde. Der er kun tre domme hvor der er idømt fængsel. Den nyeste af dem er dommen fra byretten i Østisland 2007 om klorgassen i svømmehallen, hvor den ene af de tiltalte blev idømt 30 dages betinget fængsel. De to andre domme er Højesteretsdomme, fra henholdsvis 1984 og 1993, hvor falke blev fjernet fra deres rede. I begge domme blev den ene af de to skyldige idømt 3 måneders ubetinget fængsel, men den anden fik mildere straf.

Bøderne er meget milde, i de fleste byretsdomme mindre end IKR 100.000. I fire domme er den højere. I H 18. jan. 2007 (bulldozeren) og H 23. maj 2001 (rensdyrjagt), er der idømt IKR 200.000 i bøde. Forvandlingsstraffen giver dog bedre billede af straffen og i dommen fra 2007 var den 14 dage, men 30 dage $\mathrm{i}$ dommen fra 2001. I byretten i Vestfjordene 18. juli 1999 (gravning af affald uden tilladelse), var bøderne for individerne IKR 200.000 og 400.000, med forvandlingsstraf på 30 og 45 dage. Kommunen fik den strengeste straf, bøde IKR 800.000. De højeste bøder var i Højesteretsdommen om skibet som blev trukket ud på havet (H 11. marts 1999), IKR 2.500.000 for den ene af de tiltalte, med forvandlingsstraf 5 måneder og IKR 500.000 for den anden, med forvandlingsstraf 60 dage. Det ser ud til at være fælles angående strafudmåling i de domme med de strengeste straffe at det fremhæves, at forbrydelserne er begået mod landets sarte natur.

\section{Konklusion}

Af det som her er beskrevet står det klart, at der er meget som ikke virker i disse sager i Island. Lovgivningen er mangelfuld. I nogle af lovene er der ingen gerningsbeskrivelser, eller de som dog findes er upræcise, og bestemmelserne $\mathrm{i}$ de forskellige bekendtgørelser er ikke skrevet ud fra det synspunkt at de skal fungere som straffebestemmelser. Få sager bliver anmeldt og hvis de bliver anmeldt så kommer de sjældent til højere instans end politiet. Politiet har meget travlt, og har andre prioriteringer end disse sager, som sjældent forstås som alvorlige sager.

Det er klart at den mangfoldige og alvorlige fare både nulevende og fremtidige generationer står over for er kun i begrænset omfang en opgave for strafferetten og anvendelse af straf er ingen løsning på disse problemer. På den anden side kan straf fungere som et af de midler der kan bruges for at forhindre alvorlige overtrædelser mod miljøet og dermed bidrage til at bevare et rent og uforurenet miljø. Straf kan også medvirke til at skabe den moralske holdning at naturen skal omgås med respekt, men indtil nu har miljøforbrydelser ikke været objekt for den samme moralske fordømmelse som mange traditionelle forbrydelser. 


\section{Litteratur}

Gunnar G. Schram: Umhverfisréttur. Verndun náttúru Íslands. (Miljøret. Beskyttelse af Islands natur). Reykjavík 1995.

Ragnheiður Bragadóttir: Iceland. Umweltstrafrecht in den nordischen Ländern. Max-PlanckInstitut für ausländisches und internationales Strafrecht. Arbeiten zum Umweltrecht 10. Freiburg im Breisgau 1994.

Ragnheiður Bragadóttir: Hugtakið umhverfisbrot og ákvæði almennra hegningarlaga er lýsa slíkum brotum. (Begrebet miljøforbrydelse og straffelovens bestemmelser som kan defineres som miljøforbrydelser). Úlfljótur Afmælisrit 50 ára. Orator, Félag laganema, Reykjavík 1997.

Ragnheiður Bragadóttir: Miljøproblemer i Island set i et strafferetligt perspektiv. Rapport 34. nordiske forskerseminar i Gilleleje, Danmark 1992. Nordisk Samarbeidsråd for Kriminologi, Oslo 1992.

Ragnheiður Bragadóttir: Kørsel udenfor veje. Festskrift till Per Ole Träskman. Norstedts Juridik. Stockholm 2011.

Sigurður Örn Guðleifsson: Mengunarbrot. (Strafbar forurening). Meistaranámsritgerð í umhverfisfræðum við lagadeild Háskóla Íslands. (Masterafhandling i miljøvidenskab. Det juridiske fakultet, Islands universitet). Reykjavík 2002.

Umhverfi og auðlindir - Stefnum við í átt til sjálfbærrar próunar? (Miljø og naturresurser - På vej mod en bæredygtig udvikling?) Umhverfsiráðuneytið (Miljøministeriet) 2009.

\section{Noter}

1. Ragnheiður Bragadóttir er professor ved det Juridiske Fakultet, Islands Universitet.

2. Se fx forarbejderne til lov nr. 122/1999 om ændring i straffeloven og lov nr. 20/2012 om ændring i naturværnloven.

3. Straffeloven nr. 19/1940 med senere ændringer.

4. Ragnheiður Bragadóttir: Hugtakið umhverfisbrot og ákvæði almennra hegningarlaga er lýsa slíkum brotum. (Begrebet miljøforbrydelse og straffelovens bestemmelser som kan defineres som miljøforbrydelser), s. 232.

5. Den femte kategori er lov om planlægning og byggelov. De omtales ikke i denne artikel. Her kan også nævnes to nye love. For det første er det lov om miljøansvar, nr. 55/2012, som handler om ansvar for miljøskader på grund af erhvervsvirksomhed. For det andet er det lov om klima, nr. 70/2012, men ifølge dem straffes det med bøde eller fængsel indtil ét år, at give forkerte oplysninger til Miljøbestyrelsen.

6. Se: Ragnheiður Bragadóttir: Kørsel udenfor veje. Festskrift till Per Ole Träskman. s. 92-101.

7. Sigurður Örn Guðleifsson: Mengunarbrot. (Strafbar forurening). Meistaranámsritgerði í umhverfisfræðum við lagadeild Háskóla Íslands. (Masterafhandling i miljøvidenskab. Det juridiske fakultet, Islands universitet). Reykjavík 2002.

8. Tallene i parentes henviser til forvandlingsstraffen som i dette tilfælde var 14 dages fængsel. 